Études/Inuit/Studies

Technologies créatives: expérimentation et pratiques sociales dans les sociétés arctiques

Creative technologies: Experimentation and social practice in Arctic societies

\author{
Nancy Wachowich
}

Volume 34, numéro 2, 2010

Technologies créatives

Creative technologies

URI : https://id.erudit.org/iderudit/1003777ar

DOI : https://doi.org/10.7202/1003777ar

Aller au sommaire du numéro

Éditeur(s)

Association Inuksiutiit Katimajiit Inc.

Centre interuniversitaire d'études et de recherches autochtones (CIÉRA)

ISSN

0701-1008 (imprimé)

1708-5268 (numérique)

Découvrir la revue

Citer cet article

Wachowich, N. (2010). Technologies créatives: expérimentation et pratiques sociales dans les sociétés arctiques / Creative technologies: Experimentation and social practice in Arctic societies. Études/Inuit/Studies, 34(2), 5-19.

https://doi.org/10.7202/1003777ar 


\title{
Technologies créatives: expérimentation et pratiques sociales dans les sociétés arctiques
}

\author{
Rédactrice invitée: \\ Nancy Wachowich*
}

\section{Introduction}

Lorsque nous évoquons la vie des Inuit dans l'Arctique, nous pensons souvent à des gens qui s'adaptent à des conditions extrêmes en utilisant des technologies solides et durables — objets durs ou mous, objets inertes faits de pierre, d'os, de métal, de bois, de peau, de fourrure, de neige ou de glace. Nous pensons également aux outils, à l'équipement, aux instruments ou aux dispositifs qu'utilisent les Inuit pour procurer de la nourriture et un abri à leurs familles. Mais les technologies doivent-elles toujours être relatives à des objets matériels, que l'on tient fermement dans la paume de main ou sous le pied? Autrefois, les peuples chasseurs nomades du nord voyageaient léger. Ils n’emportaient que quelques outils, le reste était fabriqué sur place. La technologie n'était pas forcément portée sur le dos d'une personne, étroitement ficelée sur un traîneau ou placée au fond d'un bateau; elle pouvait également être une pensée dans la tête de quelqu'un. La technologie ne se composait pas que d'objets, mais aussi de la connaissance et des savoir-faire nécessaires pour fabriquer ces outils, qui pouvaient être rejetés ou irrémédiablement perdus, avant d'être re-fabriqués, encore et encore, en improvisant avec les matériaux que l’on trouvait à portée de la main.

Avec les épisodes de contacts culturels, les technologies de chasse en sont venues à inclure les matériaux, outils, savoir-faire, systèmes de connaissances et relations sociales que l’on reconnaît généralement pour faire partie — voire pour être le lot — de la société industrielle occidentale. Savoir manier les fusils, les radios, les véhicules tout-terrain et les motoneiges est devenu aujourd'hui aussi nécessaire à la subsistance et à la survie des Inuit que l'était autrefois le fait d'apprendre à utiliser un harpon ou conduire un équipage de chiens de traîneau. Mais comment pourrions-nous qualifier ces instruments et pratiques sociales emblématiques des modes de vie sédentaires (plutôt que nomades), ou celles qui se concentrent sur le bien-être de la communauté, ou celles qui permettent la communication et l'interaction, au niveau local et à un niveau plus global? Comment envisager ces pratiques qui combinent les médias imprimés traditionnels et les nouveaux réseaux sociaux électroniques? De telles réévaluations et reconfigurations de nos idées reçues au sujet de la technologie devraient-elles inclure les pratiques créatives, relationnelles, idéologiques et souvent

Department of Anthropology, University of Aberdeen, Aberdeen, Scotland, AB243QY, U.K. n.wachowich@abdn.ac.uk

ÉTUDES/INUIT/STUDIES, 2010, 34(2): 5-11 
immatérielles? En quoi l'extension de notre manière d'envisager la «pratique technologique» pourrait-elle modifier l'envergure et l'orientation des études empiriques à l'avenir, et ainsi permettre de nouveaux points de vue sur les formes contemporaines de l'adaptation culturelle en Arctique?

Avant d'atteindre un objectif si ambitieux, nous devons d'abord revenir sur l'histoire du traitement réservé par les chercheurs à la culture matérielle des Inuit. Les outils inuit ont une place prééminente dans les représentations ethnographiques d’êtres humains vivant et s'adaptant à des environnements locaux particuliers. Les parkas de peau, les kayaks, les outils de chasse et le matériel de couture fabriqué à partir de matériaux organiques furent recueillis par les explorateurs et naturalistes de l'Arctique puis montrés au public dans les expositions ethnographiques des musées du $19^{\mathrm{e}}$ siècle. La pensée du temps plaçait les peuples chasseurs au bas de l'échelle de l'évolution culturelle; les expositions décrivaient donc les Inuit comme étant plus proches de la nature et moins «civilisés» que les groupes d'agriculteurs plus «sophistiqués» sur le plan technologique et plus «avantagés» sur le plan matériel (Bravo 2002; de Laguna 1994; Stocking 1988). Au début du $20^{\mathrm{e}}$ siècle, les perspectives relativistes ont largement supplanté ces hiérarchies évolutionnistes des cultures. De nouveaux intérêts, alimentés par les théories de l'adaptation culturelle et du particularisme historique, ont amené la production de collections ethnographiques, d'inventaires et de catalogues d'outils inuit spécialisés, ainsi que des techniques qui leur étaient associées, en soulignant les moyens de survie particuliers aux Inuit dans ce que l'on percevait généralement comme un environnement dur et hostile (Birket-Smith 1929; Boas 1888; Mathiassen 1928).

Dans les années 1960, les descriptions ethnographiques d'un «complexe utilitariste» fait de «neige, de peau, d'os et de pierre» - en opération chez les Netsilingmiut (Balikci 1970) — étaient devenues un élément clé des programmes scolaires et des cours des étudiants au premier cycle en anthropologie. Cette «théorie du complexe culturel» a produit une puissante culture visuelle. Les images et les récits des techniques de chasse des Inuit et de leurs ingénieux outils faits de pierre, de neige, d'os, de peau, de plume, de métal et de bois brossaient le portrait d'une relation intime et symbiotique entre les Inuit et leur environnement physique. Ces savoir-faire traditionnels et les complexes matériels sont devenus la pierre angulaire de la culture, et parfois même également un rempart à l'aune duquel peuvent se mesurer les effets de l'assimilation. Aujourd'hui, à une époque où la géopolitique se modifie, où l'exploitation industrielle des ressources s'accroît, où le changement climatique empire et avec les préoccupations croissantes au sujet de la souveraineté en Arctique, notre intérêt pour la manière dont les Inuit articulent leurs relations à leur environnement par le biais des pratiques matérielles et technologiques connaît un renouveau de légitimité, en même temps qu'un caractère d'urgence (Bravo et Triscott 2010).

L’argument clé sur lequel se fondent les contributions à ce volume est le suivant: la technologie ne peut se définir si étroitement qu'elle n'engloberait que les instruments eux-mêmes (organiques ou mécaniques), elle doit également inclure les processus sociaux qui font partie de la pratique matérielle. Une compréhension ainsi élargie exige

\section{6/N. WACHOWICH}


que l'on fasse des distinctions analytiques entre les termes dérivés de la conception communément admise de la technologie. La technique (les savoir-faire des sujets humains) doit être distinguée de la technologie - «le corpus du savoir généralisé et objectif» ayant des applications pratiques - et des outils - «un objet qui élargit la capacité d'un agent à opérer dans un environnement donné» (Ingold 2001: 315). Cet exercice soigneux de discrimination conceptuelle n'est bien sûr pas totalement nouveau en anthropologie. À la fin du $19^{\mathrm{e}}$ siècle, l'intérêt anthropologique portait à la fois sur le produit de la technologie et sur les procédés techniques. Toutefois, cela fut supplanté par une fixation sur l'artefact lui-même, plutôt que sur l'art de sa production ou de son mode d'opération. Ce «chauvinisme de l'artefact», généralement caractéristique de la société industrielle occidentale, a contrecarré le développement d'une compréhension plus approfondie des pratiques matérielles et des stratégies adaptatives des peuples chasseurs (Ridington 1990: 86).

Pour les peuples chasseurs cueilleurs nomades du nord, la possession du savoir technique a souvent été considérée comme plus importante que la possession concrète d'outils et d'instruments (Bates 2007; Ridington 1990). Le savoir-faire pratique se transmet par l'intermédiaire de processus d'apprentissage, souvent réalisés par la pratique du récit. Les histoires orales sont fondamentales pour s'orienter sur le territoire (voir Aporta 2004; Basso 1996; Cruikshank 2005; Ingold 2000; Turnbull 2010), pour étayer des codes moraux, et pour apaiser ou aplanir les discordes ou les malaises au sein de la communauté (Cruikshank 1998). Les histoires peuvent stimuler des connexions entre le présent et le passé, ou permettre des échanges entre les communautés locales, globales et scientifiques (Cruikshank 2005; voir aussi Pasch, Wachowich et Scobie, ainsi que Sonne, dans ce volume). Pour les Inuit, les mots sont des outils qui agissent sur le monde; de ce point de vue, ils peuvent être d'efficaces sakkuit (têtes de harpons) (Therrien et Laugrand 2001: 243). Cependant, comme l'avancent dans ce volume Csoba DeHass et Drouillas, ainsi que Lincoln, il existe encore davantage de formes d'apprentissage non verbales, implicites, à l'extérieur de la sphère narrative et discursive. Envisager les technologies dans ce sens plus inclusif fraie le chemin à une riche analyse de l'esthétique fonctionnelle contemporaine des voix, des mots, des textes et de l'art. En effet, les peuples autochtones du monde entier se tournent de plus en plus vers la pratique esthétique en tant que médiatrice des rencontres interculturelles (Ginsburg 1991; Leuthold 1998; Myers 2002). Pour les peuples arctiques, l'utilisation de l'imprimé, de la vidéo, de l'art commercial et, plus récemment, des médias électroniques, a servi différentes fonctions: permettant aux gens de nourrir leurs familles (Art and Cold Cash Collective 2010; Graburn 1976, 2006; Wachowich 2006), de promouvoir des formes de continuité culturelle et, finalement, de démontrer leur souveraineté et leur autonomie culturelle auprès des instances politiques.

Afin d'illustrer la manière dont la technologie peut être reconfigurée, j'aimerais citer l'exemple d'Isuma Productions, une entreprise de production de films à Igloolik, au Nunavut. Isuma est née du croisement de la conscience culturelle métropolitaine et iglulingmiut avec les mouvements de l'art vidéo, dans les années 1960 et 1970. Le collectif Isuma est entré en opération dans les années 1980, par le biais 
d'expérimentations à petite échelle consistant à filmer les paysages arctiques et les évènements communautaires d'Igloolik. Durant les années suivantes, la circulation de leurs films à l'extérieur de l'Arctique, dans les cercles artistiques du monde non arctique, leur amena des revenus qui, en retour, permirent aux producteurs, aux acteurs et aux équipes de tournage de passer de plus longues périodes de temps dans des camps de «chasse et film» aux alentours d'Igloolik. La mise en marché et la recherche de sources de revenus extérieurs ont été essentielles à la perpétuation de la pratique filmique d'Isuma sur le territoire. Pour évaluer l'impact et le succès de cet engagement artistique, nous devons regarder au-delà de la caméra vidéo, des enregistrements et des opérations de montage pour examiner les savoir-faire, les techniques et les connaissances pratiques qu'exigent chaque scène filmée en extérieur et chaque étape de la production créative.

Pour le collectif Isuma élargi, la participation aux camps de «chasse et film» a contribué à la transmission des savoir-faire en matière de chasse et de la connaissance de l'environnement, tout en étant dépendant. Les relations sociales - entre les acteurs et les équipes de tournage, les animaux et les humains, entre membres d'une même famille et avec le grand public qui les regarde - sont toutes activées (tout comme les caméras, harpons et fusils) dans ce champ créatif d'une pratique technologique. Grâce à une aide financière de la part de conseils subventionnaires et à la reconnaissance des publics bien éloignés des limites physiques de ce lieu de vie, Isuma dispose à présent de ressources et d'un forum pour aborder les problèmes plus graves qui affectent les peuples circumpolaires. Depuis 2008, la télévision Internet fait partie de la boîte à outils d'Isuma, et les histoires orales transnationales qui se racontent en ligne sont devenues un nouveau moyen d'étendre les réseaux sociaux d'Isuma. Dans leur pratique avisée d'utilisation des médias, diverses relations sociales coexistent de manière équivalente, parallèlement à la caméra et aux enregistrements filmés.

\section{Contributions}

Les articles de ce numéro thématique abordent directement cette conceptualisation élargie de l'expérimentation créative et de la pratique technologique. Ils illustrent, de différentes manières, la nécessité d'intégrer de la sensibilité aux pratiques de production, une prise de conscience de la constitution de connaissances pratiques dans les stratégies adaptatives, et la nécessité de porter attention au complexe jeu d'échanges entre les produits matériels et les contextes immatériels. Chaque article apporte une importante contribution distinctive sur le plan théorique et empirique. Csoba DeHass et Droulias décrivent la manière dont les Aléoutes ont adapté le jeu de baseball pour répondre à leur propre logique culturelle. Ils illustrent la manière par laquelle l'activation du «jeu» permet un remodelage positif des environnements culturels. Pour les Aléoutes, le baseball est un outil. «Jouer à la balle» revient à démarquer un temps et un lieu où la communauté s'engage activement dans l'innovation et la régénération culturelles. Lincoln, de même, envisage de manière critique la régénération culturelle dans son article sur la production de «viande noire» et les soirées de vannerie artisanale au nord-ouest de l'Alaska. Pour Lincoln, le processus technologique plonge ses racines 
dans des activités traditionnelles, basées dans le territoire. Les technologies inupiat et yupiit relatives au corps s'élaborent à travers une pratique rythmée de savoir-faire relatifs au territoire, dont les produits sont à la fois matériels (viande et paniers) et immatériels (cohésion sociale, guérisons, bien-être individuel et communautaire). L'article de Pasch, de même, examine la façon dont le bien-être peut servir de moteur à la pratique technologique. En se concentrant sur les nouveaux médias en inuktitut, il cherche à montrer comment le film et les communications par les médias électroniques permettent certaines formes d'adaptation sociétale. Les caméras vidéo, et à présent Internet, proposent aux Inuit de nouvelles stratégies adaptatives dans notre monde déjà globalisé. Wachowich et Scobie envisagent également Internet comme l'outil possible d'expressions d'agir et d'autonomisation, mais soulignent aussi la manière dont ce processus commence souvent à un niveau intime, par le biais de la conception individuelle. En postant en ligne sur YouTube des vidéos descriptives de leur vie de tous les jours, les jeunes Inuit, dans l'intimité de leur propre foyer, veulent faire entendre leur voix, invitent au dialogue et alimentent de nouveaux réseaux sociaux entre leur famille, leurs amis et les lointains usagers mondiaux d'Internet. Enfin, Sonne étend le contexte historique de la construction de ce réseau en remontant au développement de la littérature inuit groenlandaise comme outil et technique de médiation des rencontres coloniales. Elle interroge les transformations créatives du mythe de Kaassassuk, variante groenlandaise du mythe pan-inuit de «l'orphelin», en soulignant les moyens par lesquels les orateurs, les auteurs et les dramaturges ont adapté cette trame narrative pour lui faire exprimer des temps de bouleversements politiques et de changements au Groenland.

Dans chacun de ces articles, la pratique technologique apparaît comme une stratégie intégrée et orientée, qui imprègne les sphères matérielle et immatérielle. Elle est reconnue comme un mode de vie dans l'Arctique, car elle exprime sans cesse de nouvelles synergies, expose des tensions productives et déteint sur un grand éventail de relations sociales entre les gens vivant en groupes familiaux dans des maisonnées, des communautés, des territoires, ou faisant partie d'une communauté «branchée», en expansion et globalisée.

\section{Références}

APORTA, Claudio

2004 Routes, trails and tracks: Trail breaking among the Inuit of Igloolik, Études/Inuit Studies, 28(2): 9-38.

ART AND COLD CASH COLLECTIVE

2010 Art and Cold Cash, Toronto, YYZ Books.

BATES, Peter

2007 Inuit and Scientific Philosophies about Planning, Prediction, and Uncertainty, Arctic Anthropology, 44(2): 87-100. 
BIRKET-SMITH, Kaj

1929 The Caribou Eskimos: Material and Social Life and Their Cultural Position, Copenhagen, Gyldendal, Report of the Fifth Thule Expedition 1921-1924, $5(1-2)$.

BOAS, Franz

1888 The Central Eskimo, Lincoln, University of Nebraska Press (republication du 6th Annual Report of the Bureau of American Ethnology for the years 1884-1884).

BRAVO, Michael

2002 Technologies of Indigeneity: Measuring the Danes and Eskimos, in M. Bravo et S. Sörlin (dir.), Narrating the Arctic: A Cultural History of Nordic Scientific Practices, Canton, Watson Publishing: 235-273.

CRUIKSHANK, Julie

1998 The Social Life of Stories: Narrative and Knowledge in the Yukon Territory, Lincoln and London, University of Nebraska Press.

2005 Do Glaciers Listen?: Local Knowledge, Colonial Encounters and Social Imagination, Vancouver, UBC Press.

de LAGUNA, Frederica

1994 Some Early Circumpolar Studies, in T. Irimoto et T. Yamada (dir.), Circumpolar Religion and Ecology: An Anthropology of the North, Tokyo, University of Tokyo Press: 7-44.

GINSBURG, Faye

1991 Indigenous Media: Faustian Contract or Global Village?, Cultural Anthropology, 6(1): 92-112.

GRABURN, Nelson

1976 Ethnic and Tourist Arts: Cultural Expressions from the Fourth World, Berkeley, University of California Press.

2006 Culture as Narrative, in P. Stern and L. Stevenson (dir.), Critical Inuit Studies: An Anthology of Contemporary Arctic Ethnography, Lincoln and London, University of Nebraska Press: 139-154.

INGOLD, Tim

2000 The Perception of the Environment: Essays on Livelihood, Dwelling and Skill, London, Routledge.

LEUTHOLD, Steven

1998 Indigenous Aesthetics: Native Art, Media, and Identity, Austin, University of Texas Press.

10/N. WACHOWICH 
MATHIASSEN, Therkel

1928 Material Culture of the Iglulik Eskimos, Copenhagen, Nordisk Forlag, Report of the Fifth Thule Expedition 1921-24, 7(1).

MYERS, Fred

2002 Painting Culture: The Making of an Aboriginal High Art, London, Duke University Press.

RIDINGTON, Robin

1990 Little Bit Know Something: Stories in a Language of Anthropology, Iowa City, University of Iowa Press.

STOCKING, George W., Jr.

1985 Objects and Others: Essays on Museums and Material Culture, Madison, University of Wisconsin Press.

THERRIEN, Michèle et Frédéric LAUGRAND

2001 Perspectives on Traditional Health, Iqaluit, Nunavut Arctic College, Interviewing Elders, 5.

TURNBULL, David

2010 Trails and Tales: Multiple Stories of Human Movement and Modernity, in M. Bravo et N. Triscott (dir.), Arctic Geopolitics and Autonomy: Arctic Perspective Cahier No. 2, Dortmund, Hatje Cantz Verlag: 71-88.

WACHOWICH, Nancy

2006 Cultural Survival and Trade in Iglulingmiut Traditions, in L. Stevenson et P. Stern (dir.), Critical Inuit Studies: An Anthology of Contemporary Arctic Ethnography, Lincoln and London, University of Nebraska Press: 119-138. 


\title{
Creative technologies: Experimentation and social practice in Arctic societies
}

\author{
Guest editor: \\ Nancy Wachowich*
}

\section{Introduction}

When we consider Inuit lives in the Arctic, we often think of people coping with harsh conditions using solid, durable technologies-hard or soft things, inert objects made of stone, bone, metal, wood, skin, fur, snow, or ice. We think also of tools, equipment, gadgets, or devices that Inuit use to provide food and shelter for their families. But must technologies always be labelled as material objects, grasped tight in the palm of the hand or firm under foot? In the past, northern nomadic hunting peoples travelled light. They carried just a few tools, the remainder were made on the spot. Technology was not necessarily carried on one's person, strapped tight to a sled or stored in a boat, but could also be a thought held in one's head. Technology was comprised not only of objects, but also of the knowledge and skills necessary to make those tools, which might be discarded or unavoidably lost, and then re-made again and again by improvising with the materials to hand.

With episodes of culture contact, hunting technologies have come to include the materials, tools, skills, knowledge systems, and social relationships that are normally recognised as part and parcel of Western industrial society. Learning the skilful operation of rifles, radios, ATVs, and snowmobiles has become just as necessary for Inuit subsistence and survival on the land today as learning to use harpoons or to drive dog-teams was in the past. But how should we speak of those instruments and social practices that are emblematic of settlement-based (rather than nomadic) lifestyles, or of those that centre on community well-being, or of those that enable communication and interaction both locally and more globally? How should we regard those practices that combine traditional print media and new digital social networks? Might such reevaluation and reconfiguration of our received notions of technology come to include creative, relational, ideological, and often immaterial practices? How might any expansion in our understanding of "technological practice" alter the scope and orientation of future empirical studies, and so provide new insights into contemporary forms of cultural adaptation in the Arctic?

Department of Anthropology, University of Aberdeen, Aberdeen, Scotland, AB243QY, U.K. n.wachowich@abdn.ac.uk

ÉTUDES/INUIT/STUDIES, 2010, 34(2): 13-19 
To meet such ambitions, we can first turn our attention back to the history of scholarly treatments of Inuit material culture. Inuit tools have had a prominent place in ethnographic representations of human beings living in, and adapting to, distinctive, local environments. Skin parkas, kayaks, hunting devices, and sewing equipment made from organic materials were collected by Arctic explorers and naturalists and placed on public display in 19th century ethnographic museum exhibits. The thinking of the day positioned hunting peoples at lower stages in cultural evolutionary development; the exhibits thus depicted Inuit as closer to nature and less "civilised" than more technologically "sophisticated” and materially "advantaged" agricultural groups (Bravo 2002; deLaguna 1994; Stocking 1988). In the early 20th century, relativist perspectives largely superseded these evolutionary rankings of cultures. New interests, shaped by theories of cultural adaptation and historical particularism, led to the production of sets of ethnographic lists, inventories, and catalogues of specialised Inuit tools and associated techniques, highlighting specific Inuit means of survival in what was generally perceived to be a harsh, inhospitable environment (Birket-Smith 1929; Boas 1888; Mathiassen 1928).

By the 1960s, ethnographic descriptions of a utilitarian "snow, skin, bone, and stone complex"-in operation among the Netsilingmiut (Balikci 1970)—became a key part of teaching curricula for schoolchildren and undergraduate anthropology students. This "complex theory" produced a powerful visual culture. Images and accounts of Inuit hunting techniques, and of tools ingeniously constructed out of stone, snow, bone, skin, feathers, metal and wood, portrayed an intimate, symbiotic relationship between Inuit and their physical environment. These traditional skills and material complexes became a cultural touchstone, and sometimes also a bulwark, against which the effects of assimilation could be measured. Today, in an era of shifting geopolitics, with increasing extractive industrial development, worsening climate change, and heightening concerns over Arctic sovereignty, our interest in how Inuit articulate their relationships to their environment through material and technological practice has a renewed legitimacy and a pressing urgency (Bravo and Triscott 2010).

The core argument shared by the contributions to this volume is as follows: that technology cannot be so narrowly defined such as only to encompass instruments themselves (organic or mechanical), but must enrol the social processes that are part of material practice. Such an expanded understanding requires that analytical distinctions be made between those terms derived from the received concept of technology. Thus, technique (the skills of human subjects) must be differentiated from technology_-"a corpus of generalised, objective knowledge" for practical application-and from tools_-"an object that extends the capacity of an agent to operate within a given environment” (Ingold 2001: 315). Such a careful exercise in conceptual discrimination is, of course, not entirely new to anthropology. In the late 19th century, anthropological interest was directed towards both the product of technology and the process of technique. However, this was superseded by a fixation on the artefact itself, rather than on the artifice of its production or operation. This "artifactual chauvinism," characteristic of Western industrial society more broadly, has thwarted the development

\section{4/N. WACHOWICH}


of a comprehensive understanding of material practices and adaptive strategies among hunting peoples (Ridington 1990: 86).

For northern nomadic hunting and gathering peoples, possession of technical knowledge has often been considered more important than actual ownership of tools and instruments (Bates 2007; Ridington 1990). Knowledge-practice is passed on through processes of enskillment, often realised through narrative practice. Storytelling is fundamental to orienting oneself in a landscape (cf. Aporta 2004; Basso 1996; Cruikshank 2005; Ingold 2000; Turnbull 2010), to upholding codes of morality, and to soothing or smoothing over community discord or ills (Cruikshank 1998). Stories can stimulate meaningful connections between the present and the past, or spark exchange between local, global, and scientific communities (Cruikshank 2005; see also Pasch, Wachowich and Scobie, and Sonne in this volume). For the Inuit, words are tools that act upon the world; in this fashion, they can be as efficient as sakkuit, ('harpoon heads') (Therrien and Laugrand 2001: 243). However, as Csoba DeHass and Drouillas, and Lincoln (this volume) argue, there are also more non-verbal, embodied forms of enskillment that exist outside the discursive-narrative realm. Understanding technologies in this more inclusive sense opens the way for a rich analysis of the contemporary, functional aesthetics of voice, word, texts, and art. Indeed Indigenous peoples worldwide are increasingly turning to aesthetic practice to mediate intercultural encounters (Ginsburg 1991; Leuthold 1998; Myers 2002). For Arctic peoples, engagement with print, video, commercial art and, of late, digital media has served different functions: enabling people to feed their families (Art and Cold Cash Collective 2010; Graburn 1976, 2006; Wachowich 2006), promoting forms of cultural continuity, and, finally, demonstrating their sovereignty and cultural autonomy to greater political constituencies.

To illustrate how technology can be reconfigured, I would like to cite the example of Igloolik Isuma Productions, a film production company in Igloolik, Nunavut. Isuma was born of the intersection of metropolitan and Iglulingmiut cultural consciousness and video-art movements in the 1960s and 1970s. The Isuma collective began operating in the 1980s through small-scale experiments filming Arctic landscapes and community events in Igloolik. The circulation of their programs beyond the Arctic in the following years, to creative arts circles in the non-Arctic world brought in revenues that, in turn, allowed producers, casts, and crews to spend extended periods of time in ancestral hunting-cum-filming camps around Igloolik. Sucessful marketing and the procurement of external sources of income have been essential for the continuation of Isuma's form of land-based filmic practice. To appreciate the impact and success of this artistic engagement, we must look beyond the video camera, the film footage, and the editing suite to investigate the skills, techniques, and knowledge-practices demanded by each setting and each stage of creative production.

For the extended Isuma collective, participation in hunting/filming camps has enabled, and been dependent on, the transmission of essential environmental knowledge and hunting skills. Social relationships-between cast and crew, animals and humans, among family members, and with the broader viewing public-are all 
activated (along with cameras, harpoons, and guns) in this creative field of technological practice. With financial assistance from funding councils and recognition from audiences existing far beyond the physical limits of the settlement, Isuma now has the resources and a forum to address larger issues affecting circumpolar peoples. Since 2008, Internet television has become part of Isuma's toolset, and transnational digital online storytelling has become a new technique to extend Isuma's social networks globally. In their media-centred, media-savvy, and media-mediated practice, diverse social relationships exist in equivalence, alongside the camera and the recorded footage.

\section{Contributions}

The papers in this theme issue directly engage this expanded conceptualisation of creative experimentation and technological practice. They illustrate, in different ways, the need to incorporate sensitivity to processual activities, awareness of practical knowledge-forming adaptive strategies, and attention to the complex interplay between material products and immaterial contexts. Each article makes its own significant theoretical and empirical contributions. Csoba DeHass and Droulias describe how Aleut have adapted the game of baseball to accommodate their own cultural logic. They illustrate the ways in which the activation of "play" allows for a positive reshaping of cultural surroundings. For the Aleut, baseball is a tool. To "play ball" means to demarcate a space and time when the community actively engages in cultural innovation and regeneration. Lincoln likewise critically considers cultural regeneration in her article on black meat processing and basket coiling craft nights in northwest Alaska. For Lincoln, the technological process is one that derives its roots from traditional, land-based activities. Inupiat and Yupiit technologies of the body are forged through rhythmic practice of land-skills, the products of which are both material (meat and baskets) and immaterial (social cohesion, healing, individual, and community wellbeing). Pasch's article similarly considers how well being can act as a driving force behind technological practice. Focusing on Inuktitut New Media, he seeks to show how film and digital communications media allow for forms of societal adaptation. Video cameras, and now the Internet, offer up new adaptive strategies for Inuit in our already globalised world. Wachowich and Scobie also consider the Internet as a possible tool for expressions of agency and empowerment, but highlight how this process can often begin on an intimate scale, through individual design. By posting “depictive” YouTube videos of everyday life online, Inuit young people, in the privacy of their own homes, claim a voice, invite dialogue, and foster new social networks between family, friends, and global web-users from afar. Finally, Sonne offers a longer historical context for this technologized network building by tracking the development of Greenlandic Inuit literacy as a tool and technique to mediate colonial encounters. She investigates creative transformations of Kaassassuk, the Greenlandic variation of a pan-Inuit "orphan myth," highlighting the ways in which its storyline has been adapted by orators, authors, and playwrights to mediate times of political upheaval and change in Greenland.

\section{6/N. WACHOWICH}


In each of these chapters, technological practice emerges as an integrated and directed strategy, one that engages material and immaterial realms. It is recognised as a way of living in the Arctic that continually captures new synergies, exposes productive tensions, and engages a broad range of social relationships between people living as families in households, communities, territories, or as part of an expansive, wired, global community.

\section{References}

APORTA, Claudio

2004 Routes, trails and tracks: Trail breaking among the Inuit of Igloolik, Études/Inuit Studies, 28(2): 9-38.

ART AND COLD CASH COLLECTIVE

2010 Art and Cold Cash-, Toronto, YYZ Books.

BATES, Peter

2007 Inuit and Scientific Philosophies about Planning, Prediction, and Uncertainty, Arctic Anthropology, 44(2): 87-100.

BIRKET-SMITH, Kaj

1929 The Caribou Eskimos: Material and Social Life and Their Cultural Position, Copenhagen, Gyldendal, Report of the Fifth Thule Expedition 1921-1924, $5(1-2)$.

BOAS, Franz

1888 The Central Eskimo, Lincoln, University of Nebraska Press (reprint from the 6th Annual Report of the Bureau of American Ethnology for the years 1884-1884).

BRAVO, Michael

2002 Technologies of Indigeneity: Measuring the Danes and Eskimos, in M. Bravo and S. Sörlin (eds), Narrating the Arctic: A Cultural History of Nordic Scientific Practices, Canton, Watson Publishing: 235-273.

CRUIKSHANK, Julie

1998 The Social Life of Stories: Narrative and Knowledge in the Yukon Territory, Lincoln and London, University of Nebraska Press.

2005 Do Glaciers Listen?: Local Knowledge, Colonial Encounters and Social Imagination, Vancouver, UBC Press. 
de LAGUNA, Frederica

1994 Some Early Circumpolar Studies, in T. Irimoto and T. Yamada (eds), Circumpolar Religion and Ecology: An Anthropology of the North, Tokyo, University of Tokyo Press: 7-44.

GINSBURG, Faye

1991 Indigenous Media: Faustian Contract or Global Village?, Cultural Anthropology, 6(1): 92-112.

GRABURN, Nelson

1976 Ethnic and Tourist Arts: Cultural Expressions from the Fourth World, Berkeley, University of California Press.

2006 Culture as Narrative, in P. Stern and L. Stevenson (eds), Critical Inuit Studies: An Anthology of Contemporary Arctic Ethnography, Lincoln and London, University of Nebraska Press: 139-154.

INGOLD, Tim

2000 The Perception of the Environment: Essays on Livelihood, Dwelling and Skill, London, Routledge.

LEUTHOLD, Steven

1998 Indigenous Aesthetics: Native Art, Media, and Identity, Austin, University of Texas Press.

MATHIASSEN, Therkel

1928 Material Culture of the Iglulik Eskimos, Copenhagen, Nordisk Forlag, Report of the Fifth Thule Expedition 1921-24, 7(1).

MYERS, Fred

2002 Painting Culture: The Making of an Aboriginal High Art, London, Duke University Press.

RIDINGTON, Robin

1990 Little Bit Know Something: Stories in a Language of Anthropology, Iowa City, University of Iowa Press.

STOCKING, George W., Jr.

1985 Objects and Others: Essays on Museums and Material Culture, Madison, University of Wisconsin Press.

THERRIEN, Michèle and Frédéric LAUGRAND

2001 Perspectives on Traditional Health, Iqaluit, Nunavut Arctic College, Interviewing Elders, 5.

18/N. WACHOWICH 
TURNBULL, David

2010 Trails and Tales: Multiple Stories of Human Movement and Modernity, in M. Bravo and N. Triscott (eds), Arctic Geopolitics and Autonomy: Arctic Perspective Cahier No. 2, Dortmund, Hatje Cantz Verlag: 71-88.

WACHOWICH, Nancy

2006 Cultural Survival and Trade in Iglulingmiut Traditions, in L. Stevenson and P. Stern (eds), Critical Inuit Studies: An Anthology of Contemporary Arctic Ethnography, Lincoln and London, University of Nebraska Press: 119-138. 